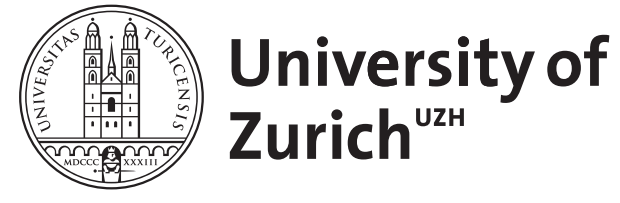

Zurich Open Repository and Archive

University of Zurich

University Library

Strickhofstrasse 39

CH-8057 Zurich

www.zora.uzh.ch

Year: 2010

\title{
Paper and Poetics
}

Giuriato, Davide

DOI: https://doi.org/10.1353/con.2010.0027

Posted at the Zurich Open Repository and Archive, University of Zurich

ZORA URL: https://doi.org/10.5167/uzh-150783

Journal Article

Published Version

Originally published at:

Giuriato, Davide (2010). Paper and Poetics. Configurations. A Journal of Literature, Science, and Technology, 18(3):211-229.

DOI: https://doi.org/10.1353/con.2010.0027 


\section{PROJECT MUSE}

\section{Paper and Poetics}

Davide Giuriato

Configurations, Volume 18, Number 3, Fall 2010, pp. 211-229 (Article)

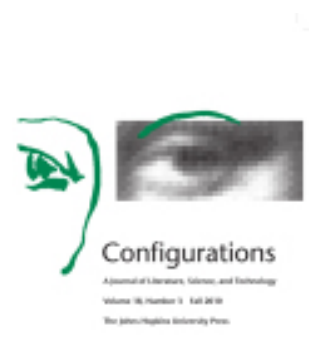

Published by Johns Hopkins University Press

DOI: https://doi.org/10.1353/con.2010.0027

$\Rightarrow$ For additional information about this article https://muse.jhu.edu/article/448146 


\title{
Paper and Poetics
}

\author{
Davide Giuriato \\ Goethe University, Frankfurt am Main
}

\begin{abstract}
The essay investigates selected writing scenes with regard to a comprehensive poetics of paper. In these scenes, writing materials are subject to literary contemplation, in accordance with their specific material properties. Size, color, texture, and even the watermarks of paper are carefully chosen by writers and can thus become part of the message. The essay examines the nexus between the writing tool and literary production, between media use and reflections on media, with examples drawn from the work of Clemens Brentano, Rainer Maria Rilke, and Walter Benjamin.
\end{abstract}

\section{Endless Paper}

The poetics of paper proffered here in the form of small, single scenes looks into the (literary) handling of a material that, for at least 200 years, has been an almost exclusive reality in the world of reading and writing. Like every other product, it also has a history.

The beginnings of the modern paper age are usually taken to be the years around 1800, although it is almost universally pointed out that decisive developments in the eighteenth century, such as the introduction of wire sieves for manufacturing vellum paper, had already laid the foundations for the industrialization of paper production in the following century. ${ }^{1}$ In 1798 the French mechanic Nicolas

1. J. Georg Oligmüller, PapierZeit (Essen, Germany: Klartext-Verlag, 1997): “The term Papierzeit is based on simple facts: the increase in the consumption of paper in Germany from around half a kilogram per head in 1800 to the 30-fold in 1900 and the 400-fold today" (p. 11). 
Louis Robert, an employee of Didot, a printer and publisher located near Paris, had invented the first paper machine, a hand-operated machine capable of producing paper "endlessly." 2 Although a year later it was patented for fifteen years, the machine was not further developed in France for a variety of reasons, the result of difficulties both inside the firm as well as broader economic and political influences.

The paper machine first evolved into a commercial product due to the investment foresight of the Fourdrinier brothers, who provide Bryan Donkin in England, a former employee at the Hall machinery factory in Dartford, with the support he needed to replace the machine's hand-operated crankshaft drive with a mechanical one. It was on this machine, in 1808 , that paper was produced continuously from the roll for the first time. However, for the optimal industrial production of paper, a series of further innovations were necessary during the following two decades, particularly concerning dewatering, the drying cylinder, the rollers to smooth the paper, and the cutting machinery. From 1830 onward numerous paper factories were established, whereby manufacturers of paper by hand were gradually, though not completely, forced out of business.

All these developments did not yet result in a dramatic increase in paper production, one reason being that the raw material for producing paper-rags-was not available in sufficient quantities. The invention of ground-wood pulp in 1844 by Friedrich Gottlob Keller, who was a weaver and reed-binder in Saxony, helped expand the raw-material base and make mass production possible. Because paper made out of this kind of pulp gradually turned yellowish-brown and crumbly, it was not a suitable substitute material for higher-quality paper, which continued to be produced by using rags, their fibers ensuring that the paper had the necessary strength and consistency. Paper made of ground-wood pulp was therefore principally used for newspapers, wallpapers, packaging materials, and so on. Chemical advancements in processing wood pulp and the implementation of cellulose fiber, which guarantees strength and a stable white finish, became the key determinants in the mass commodity of paper. Rags

2. Rolf Stümpel, "Vom Velinpapier zur Papiermaschine," in Papier, ed. Rolf Stümpel (Berlin: Museum für Verkehr und Technik, 1987), pp. 35-40; Claus Gröger, "PapierVom Aufstieg des Handgeschöpften zum unentbehrlichen Massenprodukt. Der technikgeschichtliche Wissensstand zum Grundstoff literarischer Kultur," Internationales Archiv für Sozialgeschichte der deutschen Literatur 15 (1990): 184-206; Günter Bayerl and Karl Pichol, Papier. Produkt aus Lumpen, Holz und Wasser (Reinbek bei Hamburg: Rowohlt, 1986), pp. 101-105; Peter F. Tschudin, Grundzüge der Papiergeschichte (Stuttgart: Hiersemann, 2002), pp. 138-165. 
as the primary raw material for producing paper were eventually replaced by wood and straw.

This mechanized production decisively changed the product. Paper became more uniform in thickness and new glue techniques improved the absorptive quality, strength, and binding of the fibers and generated a smooth surface, which was more consistent than the vellum paper introduced as a substitute for grosgrain-laid paper by John Baskerville, who later became the printer to Cambridge University. The scope of chemical possibilities, which grew exponentially during the late nineteenth century and were continually refined, and the addition of various bulking agents during the production process, for example, led to paper becoming a versatile product. Depending on the additive, it was now possible to precisely specify the type of paper to be manufactured: whether it was to be soft, smooth, or translucent, gray, white, or colored, depending on whether its purpose was to be for cigarette packs, flypaper, or simply writing. In 1880 precise, official directives for the production of "normal paper" were established in Germany; in terms of tension length, double edges, and material composition, distinctions were codified among eight classes (with fifteen subclasses) of utilization, from paper for documents to packaging, writing, envelope, and printing paper.

Against the backdrop of this rapid technological development of paper during the past two centuries, which has brought forth an enormous variety of types of paper, it is clear that we live in a highly differentiated paper universe, one in which everything can become a specific writing medium or surface-not only standardized writing paper, but also special materials like handmade letter paper, parchment, Japanese paper, napkins, newspaper, and so on, each possessing its own specific qualities. As we can read in a letter on the wrapping paper of the chocolatier firm Lindt \& Sprüngli that Robert Walser wrote to Frieda Mermet on 1 November 1918, the chocolates' wrapping paper itself is capable of sweetening the words written on it: "Today I'm writing to you on chocolate paper, and that's why one could well say that I'm writing you a chocolate letter [that is, one showing its best side]." 3

The format, color, and texture of paper can be part of the message and are often carefully selected by writers. At the same time, the instrumental aspect of the writing implement gains its own weight in concrete media practice, whereby its poetological relevance has to be weighed up in each individual case. My premise is that the writing 
surface is discussed, instrumentalized, and problematized in a unique way in each act of writing. ${ }^{4}$ Two examples shall highlight the singular relevance of paper, then be explicated in the form of case studies.

\section{Brentano's Watermarks}

Watermarks are the unalterable imprints of paper manufacturers that become visible when the paper is held up against the light and may be characterized as a kind of tattooed identity card. In laid paper, watermarks are created by fine strands soldered onto the wire mold; in paper machines they are created by a roller that is laid on the end-section of the sieve and pressed upon the wet webs of paper. Methods of watermark detection also give rise to a prominent and fascinating special area in the history of paper, ${ }^{5}$ which strongly resembles detective work; through these methods, known as "filigranology," ${ }^{6}$ one can determine the place and time of production of the paper-maker and so identify the type of paper, though this is possible only in ideal cases.

The importance of the watermark is not only to provide the paper with identification, but may also be of relevance because of, at times, the symbolism of the very elaborate reproductions employed. For his letter to Rahel Levin dated 14 August 1813, Clemens Brentano's selection of paper featuring a watermark of Agnus Dei, which was widespread at the time, is by no means mere coincidence. On that very same day, Brentano had already sent a letter to Levin clearly expressing his religious concerns, namely his wish that she convert to Christianity: "that you are missing an inner sanctification from divine sources, the unseen baptism, the unseen Eucharist, the unseen Christianity." 7 That the Agnus Dei symbol is used on purpose may be recognized by the space left blank in the middle of the page (fig. 1). Moreover, Brentano expressly draws the recipient's attention to the watermark when he places the following words around it:

4. Davide Giuriato, "(Mechanisiertes) Schreiben. Einleitung," in "SCHREIBKUGEL IST EIN DING GLEICH MIR: VON EISEN," Schreibszenen im Zeitalter der Typoskripte, ed. Davide Guiriato, Martin Stingelin, and Sandro Zanetti (München: Wilhelm Fink, 2005), pp. 7-20. For an aesthetics of disruption, see Dieter Mersch, Ereignis und Aura. Untersuchungen zu einer Ästhetik des Performativen (Frankfurt am Main: Suhrkamp, 2002), pp. 43-47.

5. Frieder Schmidt, ed., Papiergeschichte(n). Papierhistorische Beiträge Wolfgang Schlieder zum 70. Geburtstag (Wiesbaden: Harrassowitz, 1996).

6. This term was established by the founder of watermark studies, Charles-Moïse Briquet, who published his main work, Les Filigranes, in 1904.

7. Clemens Brentano, Sämtliche Werke und Briefe. Historisch-kritische Ausgabe, vol. 33 (Stuttgart: Kohlhammer, 2000), p. 53. 


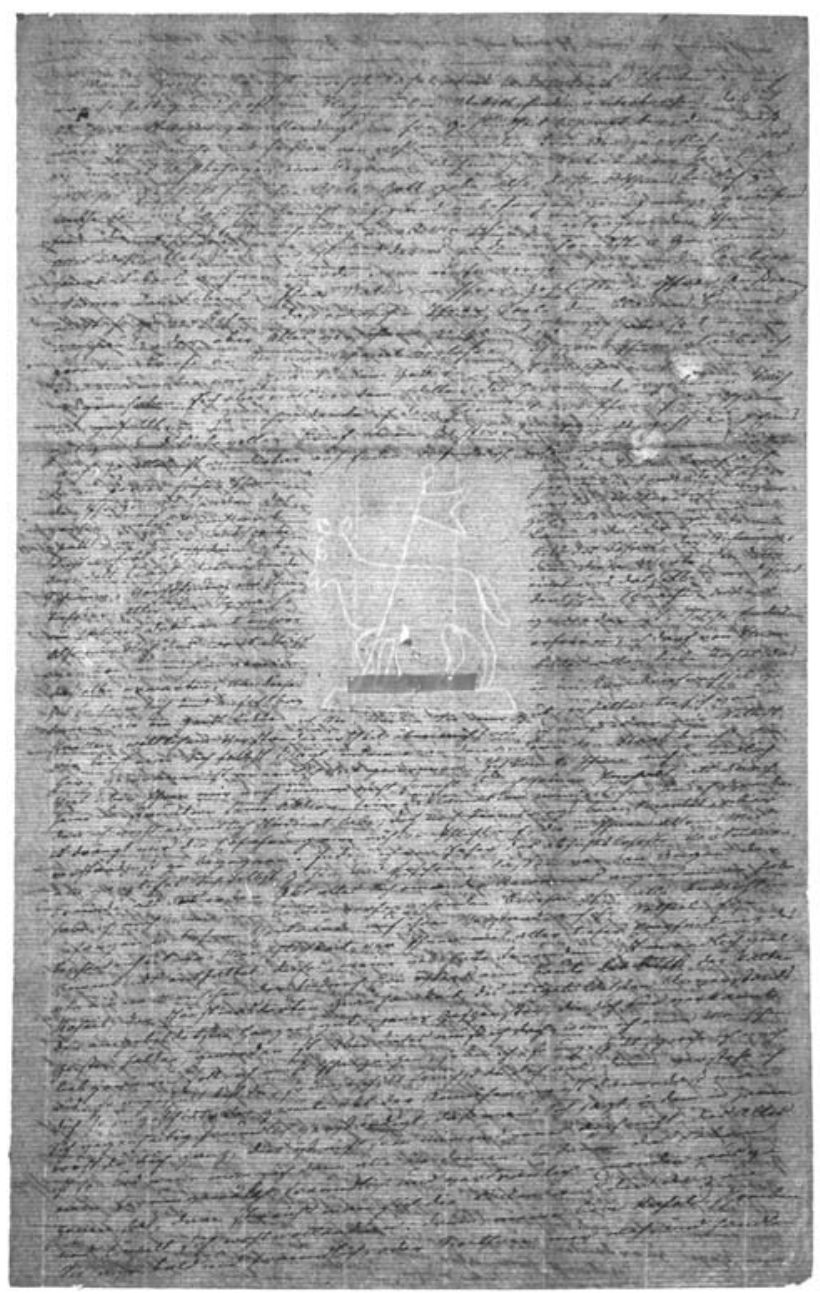

Figure 1. Letter, Clemens Brentano to Rahel Levin, 14 August 1813. (Source: Universitätsbibliothek Mainz.)

seeking amongst my sheets a paper to send you now the third letter in response to yours I found the paper mark here, which fills me with unbelievable emotion, and for me elevates the letter to a genuinely inner desire, it is that of the dear lamb, which bears the sins of the world, the touching image of the son [Sohn], begetting of the son [Sohnung], begetting of the sons [Söhnung], reconciliation [Versöhnung] and sun [Sonne], then these words are one and the same in the deepest age of the language, and are a holy document of our German language, in which the word has really become flesh. ${ }^{8}$

8. Ibid., p. 57. 
The letter, if it was actually sent, could have hardly been understood by the Jewish reader in the sense of a gesture of reconciliation; her relationship to Brentano had already been compromised in the summer of 1811 because of his anti-Semitic remarks. ${ }^{9}$ The paper itself not only becomes the real subject matter of this communication because of the poetic-religious symbolism of the watermark, but, beyond the Christian-motivated coding, the watermark stirs the writer to the language of Catholicism, to a diction that literally undertakes the attempt to attain the inseparability of flesh and word in the paronomastic word order: Sohn (son), Sohnung (begetting of the son), Söhnung (begetting of the sons), Versöhnung (reconciliation), and Sonne (sun). The paper-and this is the consequence that has to be drawn from its Catholic poetics-is staged by Brentano as an incarnated word of God. The tool character of the writing material is placed in the service of an imagination unconcerned with media and thus is transcended.

\section{Rilke's Working Paper}

The second case study reveals something else entirely. I shall draw on the brief that intensive correspondence that Rainer Maria Rilke carried on with the musician Magda von Hattingberg, whom he had not personally met, in 1914 . For Rilke, who had become mired in a creative crisis since the publication of the Aufzeichnungen des Malte Laurids Brigge (The notebooks of Malte Laurids Brigge) in 1910, the correspondence must have been a pleasant distraction; he was soon calling his reader "Benvenuta" - the welcome one. One of the wished-for prerequisites for Rilke's letter production was that he did not personally know his female correspondents; he repeatedly exchanged letters with unknown women, ${ }^{10}$ and it is by no means a coincidence that his correspondence with Benvenuta comes to an end precisely at the moment when they eventually meet one another at the end of February 1914.

Rilke persistently delayed the meeting that von Hattingberg had long cherished and sought, and in reading his letters it is obvious that this was something that, for the sake of his writing, he wanted to avoid. ${ }^{11}$ As soon as their meeting finally takes place in Berlin his

9. Ursula Isselstein, "Rahel und Brentano. Analyse einer mißglückten Freundschaft, unter Benutzung dreier unveröffentlichter Briefe Brentanos," in Jahrbuch des Freien Deutschen Hochstifts (1985), pp. 151-201.

10. Gunnar Decker, Rilkes Frauen oder Die Erfindung der Liebe (Leipzig: Reclam, 2004).

11. See Rainer Maria Rilke, Briefwechsel mit Magda von Hattingberg, ed. Ingeborg Schnack and Renate Scharffenberg (Frankfurt am Main: Insel, 2000): "Meine Freundin, kämen 
letter writing ceases and, in effect, their romance also comes to an end. Although the two spent a few intimate weeks in Berlin, Rilke soon felt the need to return to Paris, from where he let the relationship languish. In the biographical literature on Rilke, much is made of how emotional closeness and physical distance mutually condition each other, and this is seen as a leitmotif of the poet's seemingly doomed love affairs. Rilke is not a psychologist, but an analyst of aesthetic media; his letters baldly dismantle the foundation pillars of the epistolary exchange-namely, the instance of sender and receiver. That exchanging letters is not actually about correspondence, but is founded rather on a monologic structure, is something that Rilke addresses directly: "My dearest, don't think that you have to respond to every one of my letters, just be there, just be there."12 Rilke tells this to a clearly irritated correspondent, who answers with the helpless question: "What do you mean ... 'don't think [that] you have to respond to every one of my letters'?"13 A question that Rilke does not clarify.

The thesis that, on Rilke's part, the correspondence bears all the signs of an intended literary practice is evident in his choice of paper alone. Contrary to the habit of writing letters on well-caredfor, lightly toned and unlined paper, those to his addressee are on square-patterned working paper, as Rilke mentions apologetically at the very outset of the exchange: "My paper, the letter paper, has now arrived, my good friend, but I wish to be boastful and say it was always my habit to write to you on what I usually work, so let it stay so." ${ }^{14}$ Two aspects of this statement deserve to be emphasized: first, Rilke reveals the material he uses for his literary work-namely, light, lengthwise squared paper from octavo pads (fig. 2); and second, it can be observed that Rilke's selection of the paper for his writing production is very careful and semiotically strictly distinct: high-quality paper indicates letters, and conventional paper indicates literature.

Consequently, we can say that the material of the writing medium is not neutral for Rilke, but that paper and its specific qualities

Sie doch—, dann wieder, wenn ich denke, wir sähen uns, ist mir, als betrög ich Sie" (My friend, come then-, but then again when I think that we will see each other, it seems to me as if I'd be cheating you) (p. 34); and "Ich glaube die Ferne ist ein Weg, auf dem ich wehrloser erreichbar bin, als durch jede Nähe" (I believe that distance is a path upon which I am approachable more defenselessly than any closeness) (p. 124).

12. Ibid., p. 139.

13. Ibid., p. 147.

14. Ibid., p. 27. 


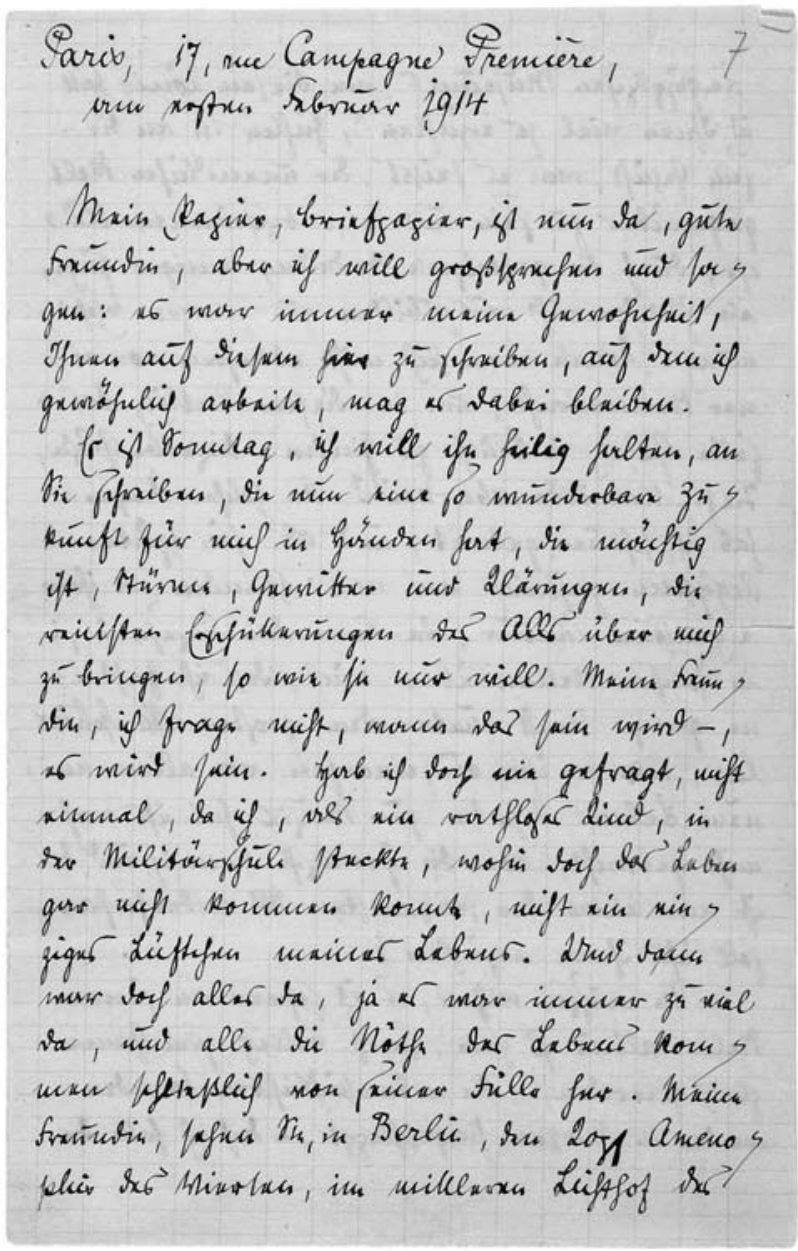

Figure 2. Letter, Rainer Maria Rilke to Magda von Hattingberg, 1 February 1914. (Source: Deutsches Literaturarchiv Marbach a.N.)

play a part in determining the relevance of what is written. Thus through the selection of the writing material, poetical production and letter writing coincide, their distinctiveness fading. As paper is literally coded, this situation initiates a double message, one epistolary and the other literary. In the process, the instrumental function of the paper is not disturbed-that is, the message is sent off and can be read unhindered. In addition, however, the paper possesses for the writer a literary function, because the square-patterned working paper is accordingly defined in Rilke's practice-a moment that he intentionally deploys in the exchange of letters. After the disap- 
pointing meeting, Rilke now wrote all his subsequent letters to von Hattingberg on the usual letter paper: "and so it ends up after all that you finally get to know my letter paper-, Magda; it tells you straightaway, in its distinct way, where I am again, and stay." Thus Rilke wrote to finish, as it were, the affair (fig. 3). ${ }^{15}$

Rilke's material poetics is far removed from Brentano's paradoxical transcending of the writing medium, insofar as Rilke can arbitrarily code and, as in the case of Benvenuta, recode his paper based on its material composition. Both examples show, however, that paper is not just some neutral material external to the message conveyed or the act of communication, but that it is indeed an integral component of the same. I would like to now explicate Walter Benjamin's practice of handling writing paper against this background and relate his actual use of the medium, as one who traditionally dealt with the neutrality and productivity of the writing surface, regarding a "poetological figure"-namely, the "figure of the blank page."

\section{Walter Benjamin's Paper Recycling}

Walter Benjamin's writing is inextricably linked to how he handles those materials usually considered to be external to and secondary for the writing process, whether this be in the area of fiction, essays, or philosophy. At the same time, however, the writing implement (for example, its unwieldiness, its tractability, its self-will), the place of writing (for example, outdoors, at home, the desk), and even the physical state and sensitivities of the writer are of primary importance in the literature of Modernism, precisely because of their specific materiality. This applies to the extent that they become objects of poetic or poetological reflections and experiments, which Roland Barthes has characterized as "intransitive writing." The modern writer no longer writes only about "something," but his or her involvement is absolute, in that the activity is accordingly detached from the possible outcome of writing; it remains primarily bound to its physical and material realization. ${ }^{16}$

Studies regarding the writing process explore the cases of "paper workers," in contrast to "mind workers." ${ }^{17}$ For the latter, writing ac-

15. Ibid., p. 184. See also Davide Giuriato, "Die unwirthlichen Blätter. Rilke, das Papier, die Post und die Briefe an Benvenuta," in Der Brief. Ereignis und Objekt, ed. Waltraud Wiethölter and Anne Bohnenkamp (Frankfurt am Main: Stroemfeld, 2010), pp. 134-146.

16. Roland Barthes, Le bruissement de la langue. Essais critiques IV (Paris: Seuil, 1984), pp. 21-31.

17. Almuth Grésillon, "Über die allmähliche Verfertigung von Texten beim Schreiben," in Kulturelle Perspektiven auf Schrift und Schreibprozesse, ed. Wolfgang Raible (Tübingen: Narr, 1995), pp. 1-36. 


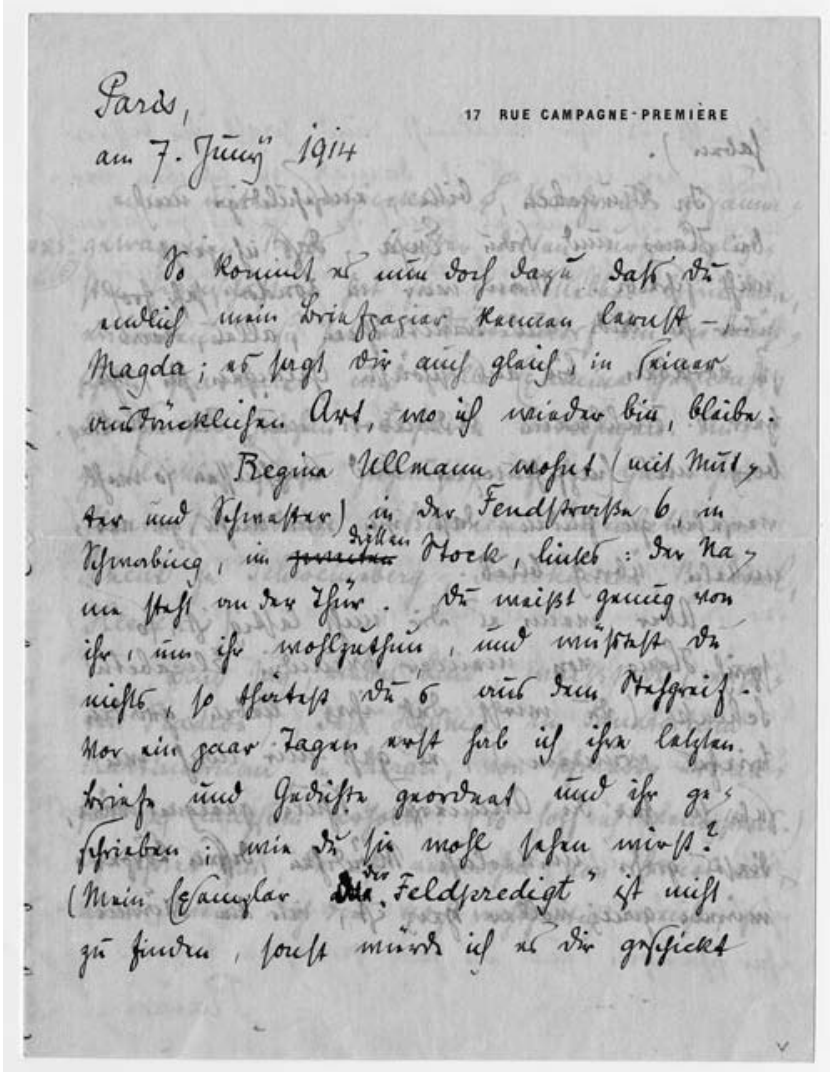

Figure 3. Letter, Rainer Maria Rilke to Magda von Hattingberg, 7 June 1914. (Source: Deutsches Literaturarchiv Marbach a.N.)

tually means a mental process that is first concluded in the mind before being set down on paper, as if by magic. For paper workers, though, writing is not the expression of thinking, but its very realization. Thinking is not necessarily the precondition for writing, it need not be antecedent, being just as feasibly a posteriori. For paper workers, the writing utensils, suitable paper, and favorable circumstances-in short, fluent, trouble-free writing-is not the rule, but an "Arcadia," as Benjamin put it in his Einbahnstraße (One way street) (1928). ${ }^{18}$ There are disturbances, phases of stagnation,

18. All texts by Benjamin are quoted from either Gesammelte Schriften (hereafter GS) or Gesammelte Briefen (hereafter GB) (Walter Benjamin, Gesammelte Schriften, ed. Rolf Tiedemann and Hermann Schweppenhäuser [Frankfurt am Main: Suhrkamp, 1974-89]; and Walter Benjamin, Gesammelte Briefe, ed. Christoph Gödde and Henri Lonitz 
and hindrances encountered by paper workers in particular. Writing appears to suspend itself wherever it does not function smoothly and wherever it breaks down into its components. The hand, the writing implement, and the mind can all become entangled in a conflict with one another and at times even go their own separate ways. ${ }^{19}$ Therefore as a rule, surfaces and media studded with crossedout lines and words, superimposed phrases and words, insertions from the margins and between lines, additions, and so on are the outcome, whereby the struggle to achieve a definitive form is clearly visible.

Such a material poetic corresponds to Benjamin's numerous remarks on writing, and indeed to his own writing practice. All areas of the activity of writing are discussed by Benjamin in terms of their materiality and as considered in actual practice. ${ }^{20}$ His production was decidedly hand-written-one that, viewed from the perspective of media history, refused using a typewriter-and is thus defined in its distinctiveness from a standardized typeface. This is the source for the attention paid to the fountain pen, the "tyranny" of which Benjamin likewise bemoans, or to the writing surface, which he at times filled with the smallest possible handwriting. This is also the source for his interest in the outward appearance of script, expressed in his reflections on the visual impression made by the written word, graphology, and calligraphy.

But also the physical act of writing by hand-for instance, as in the practice of copying, an activity that he pursued methodically when composing his own texts-he considered a virtue as compared to typed text. Benjamin must have felt that the transition into print and typography, which he followed with great attention-as the printing of Einbahnstraße and Ursprung des deutschen Trauerspiels (The origin of German tragic drama) testify-to be a threshold, one that he did not consider necessary to cross in each and every case. For the publication of Lehre vom Ähnlichen (Doctrine of the similar) he

[Frankfurt am Main: Suhrkamp, 1995-2000]). Here, Benjamin's quote is from GS, vol. 4, p. 113. The English translations of Benjamin's works and letters used in this text are based on, where applicable, the following: Walter Benjamin, Selected Writings, 19131926, vol. 1, ed. Marcus Bullock and Michael W. Jennings (Cambridge, MA: Harvard University Press); and Selected Writings, 1927-1930, vol. 2, pt. 2, ed. Michael W. Jennings, Howard Eiland, and Gary Smith (Cambridge, MA: Harvard University Press).

19. Martin Stingelin, "Schreiben. Einleitung," in "Mir ekelt vor diesem tintenklecksenden Säkulum". Schreiben im Zeitalter der Manuskripte (München: Wilhelm Fink, 2004), pp. 7-18.

20. Walter Benjamin Archiv, ed., Walter Benjamins Archive. Bilder, Texte und Zeichen (Frankfurt am Main: Suhrkamp, 2006). 
remarks: "I'm not going to allow these pages to be printed, I'm not even sure if they are even able to be transmitted by a machine." ${ }^{21}$

But what is the place of paper in this poetics? Benjamin leaves no doubt that selecting the material needs to be based on a calculated strategy, declaring in Die Technik des Schriftstellers in 13 Thesen "Pedantic adherence to certain papers, pens, inks is beneficial."22 Elsewhere, in a stylized self-portrait, he states: "He has to have a specific lighting for his desk and a specific type of paper and a specific sheet size, otherwise he cannot work." ${ }^{23}$ Statements like these and documents from his estate confirm that Benjamin avoided standard items. ${ }^{24}$ The format of notepads, for instance, was to be preferably smaller than A6 (ISO 216: $105 \times 148 \mathrm{~mm}$ ) and served the tiny script that Benjamin often wrote in. Gershom Scholem tells of Benjamin's ambition to fit a hundred lines on a letter page. Pages written by Benjamin are usually full; empty space is rare.

In addition to the size of the paper, it is striking that Benjamin preferred tinted sheets-chamois or light gray; occasionally he used other colors: for instance, red or blue. In a letter to Julia Radt he writes: "Dear Julia—with these words I'm celebrating a double induction: that of my fountain pen and these sheets of paper, which are to be used as letter paper only for you - they are otherwise my most precious manuscript paper in a hue I have searched long and hard for and which lures the best ideas out of me."25 The topos of virginal, innocent paper is evoked, the topos of the blank page that recalls the delicate moment of putting pen to paper, of starting to write, and the elegiac problem of "writer's block," of not-being-able-to write. ${ }^{26}$

21. GB (above, n. 18), vol. 4, p. 163: "Drucken lasse ich besagte Blätter nicht, ja ob sie auch nur einer Maschinenübertragung fähig sind, erscheint mir noch nicht ganz sicher." For a systematic description of Benjamin's material poetics, see Davide Giuriato, Mikrographien. Zu einer Poetologie des Schreibens in Walter Benjamins Kindheitserinnerungen (1932-1939) (München: Wilhelm Fink, 2006), pp. 27-59.

22. GS (above, n. 18), vol. 4, pt. 1, p. 113: "Pedantisches Beharren bei gewissen Papieren, Federn, Tinten ist von Nutzen."

23. Ibid., vol. 4, pt. 2, p. 776: "Er muß eine ganz bestimmte Schreibtischbeleuchtung und ein ganz bestimmtes Papier und ein ganz bestimmtes Format seiner Bogen haben, sonst kann er nicht arbeiten."

24. Erdmut Wizisla, "Verzettelte Schreiberei," in Sinn und Form (2006), pp. 266-273.

25. GB (above, n. 18), vol. 3, p. 150 (Brief vom 30. April 1926): “Liebe Julia-mit diesen Worten vollziehe ich eine doppelte Einweihung: die meines neuen Füllfederhalters und dieser Bogen, die freilich nur für Dich als Briefpapier gelten—sonst sind sie mein kostbarstes Manuscriptpapier in einer Tönung, nach der ich lange gesucht habe, und die die besten Gedanken aus mir herauslockt."

26. See Vom Schreiben I-Das weiße Blatt oder Wie anfangen? (published in Marbacher 
This image of a precarious creative act does not seem to present a problem for Benjamin: where the blank page could mean a case of writer's block, Benjamin appears to have a practical solution at hand. It is characteristic of his production that when he evokes the topos of the blank page, he does not do this on a white sheet of paper but on a tinted one, for Benjamin systematically avoids using white paper. It seems that he replaces the notion of a neutral medium associated with the topos of a white sheet of paper with a practice of working on sheets already used, which are characterized by decidedly aesthetic qualities and not semiotic ones. It is therefore no wonder that Benjamin fervently practiced paper recycling. He favored writing on the rear side of drafts for letters or on letters he had received, on forms, advertising leaflets, or prescription pads.

But regarding this as an expression of ecological awareness would be exaggerated; Benjamin's preferences for using material already written or printed on and for tinted-namely, preprocessed-paper are more logical and coherent when viewed from the perspective of a poetics of reuse. Like a palimpsest, which does not erase the antecedent script, production always begins where something already is. Benjamin thus circumvents the dilemma posed by beginnings, which is always possible when confronted with a blank page, by employing mechanical approaches and procedures, which may be subsumed under the common denominator of "recycling." ${ }^{27}$ This is not to say, however, that, once and for all, the question of the genesis of texts is resolved for Benjamin; on the contrary, his problematization of the act of commencing writing is closely related to the paper, both literally and poetologically.

\section{Blotting Paper}

In Benjamin's project focusing on childhood memories, later published as Berliner Chronik (Berlin chronicle) and Berliner Kindheit um 1900 (Berlin childhood around 1900), there is a passage that reflects on the genesis of the text. Benjamin recalls an afternoon in Paris when the idea for the project came to him:

Now on the afternoon in question I was sitting inside the Café des Deux Magots at St Germain des Prés where I was waiting - I forget for whom. Suddenly,

Magazin 68), ed. Ulrich Ott (Marbach am Neckar, 1994); Thomas Macho, "Shining oder: Die weiße Seite," in Weiß, ed. Wolfgang Ulrich and Juliane Vogel (Frankfurt am Main: S. Fischer, 2003), pp. 17-28.

27. Manfred Schneider, "Der Barbar der Bedeutungen: Walter Benjamins Ruinen," in Ruinen des Denkens_Denken in Ruinen, ed. Norbert Bolz and Willem van Reijen (Frankfurt am Main: Suhrkamp, 1996), pp. 215-236. 
and with compelling force, I was struck by the idea of drawing a diagram of my life, and knew at the same moment exactly how it was to be done. With a very simple question I interrogated my past life, and the answers were inscribed, as if on their own accord, on a sheet of paper that I had with me. A year or two later I was inconsolable as I lost this sheet. I have never been able to produce it in the same way as it gestated in front of me at that time. But now, as I reproduce its schema in my mind without being able to precisely replicate it, I would prefer to speak of a labyrinth. ${ }^{28}$

This account of how the act of writing began shows an intangible and compelling genesis of its own text of recollection. It is a lightning-like and involuntary intuition that Benjamin describes, borrowing from Proust, sections of whose $\dot{A}$ la recherche du temps perdu he translated between 1926 and 1929. In this light, the reference to a Paris café is not coincidental, for elsewhere in the text Benjamin emphasizes that he wants his recollection of his childhood in Berlin to be understood as a kind of transcription of Proust's Parisian memories-as another form of translation of his literary predecessor. ${ }^{29}$ The involuntary and initial intuition takes place, automatically, on a sheet of paper. Here it is, once again, the invisible magic hand through which writing flows unopposed.

As Benjamin then goes on to explain, this first page-the original-had been lost, and that despite efforts to reproduce it, restitution had proved impossible. The singularity of the initial writing

28. GS (above, n. 18), vol. 6, p. 491: "An dem Nachmittag nun, von welchem ich reden will, saß ich im Innenraum des Cafés des deux magots bei St Germain des Prés, wo ich—wen habe ich vergessen-erwartete. Da kam mit einem Male und mit zwingender Gewalt der Gedanke über mich, ein graphisches Schema meines Lebens zu zeichnen und ich wußte im gleichen Augenblick auch schon genau wie das zu tun sei. Es war eine ganz einfache Frage, mit der ich meine Vergangenheit durchforschte und die Antworten zeichneten sich wie von selber auf ein Blatt, das ich hervorzog. Ein oder zwei Jahre später als ich dieses Blatt verlor, war ich untröstlich. Nie wieder habe ich es so herstellen können, wie es damals vor mir entstand. Jetzt aber, da ich in Gedanken seinen Aufriß wiederherstellen möchte ohne ihn geradezu wiederzugeben, möchte ich lieber von einem Labyrinth sprechen."

29. Ibid., p. 467: “Kaum wäre es mir möglich, dem Hin und Wieder dieser Erinnerungen an mein frühestes Stadtleben mich zu überlassen, stünden nicht von Paris her streng umschrieben die beiden einzigen Formen vor mir, in denen das auf legitime Art ... geschehen kann. . . . Die erste Form ist geschaffen im Werke von Marcel Proust und der Verzicht auf jedes Spielen mit verwandten Möglichkeiten wird schwerlich eine bündigere Gestalt finden, als die der Übersetzung" (It would barely be possible for me to surrender to this now and then of the memories of my earliest life in a city if not the two sole forms were in front of me, coming from Paris, in which this can occur in a legitimate way. ... The first form is created in Marcel Proust's work and renouncing any playing with related possibilities will have difficulty finding a more concise form than the translation). 
event has thus eluded transmission; what remains are futile attempts at reconstruction, about which the writer desists from explaining. This lost beginning of a manuscript concerned with memory and the act of remembering has a correspondence on the level of the actual writing process. Without being able to deal in detail with the complexity surrounding the genesis of Berliner Kindheit um 1900, it may nevertheless be stated that there is no precisely determinable beginning for the text or the writing process. ${ }^{30}$ But here the situation is rather different: Benjamin starts again to write brief texts about his childhood memories in a variety of locations, even publishes them when the opportunity arises and compiles them into a book, only to then rewrite this book again and again, which is completely in line with the procedure of recycling.

Among the several sheets of this diverse, random production, there is indeed a "diagram" of Benjamin's life that he had jotted down in a notebook, which looks exactly like the account he gave in his text as he described its beginning in that Parisian café. ${ }^{31}$ One can take a chronological/biographical line and pursue the question whether this was now the initial act of writing about which the text tells us, which had gone astray, and then go on to determine that, should the autobiographical account seem credible, it was probably one of the failed attempts to reproduce the original. ${ }^{32}$ But the entire issue is not so clear-cut: the question about the beginning defies a purely positivistic answer.

On the poetological level, though, it may be noted that the story was written from the position of a lost beginning, and hence reflects a deferral. From this perspective, one can say of Benjamin's childhood memories that time and again they began anew, without ever really possessing a "beginning" in an emphatic sense. Among other things, this explains why his autobiographical story does not follow a chronologically linear model, but expressly relies upon discontinuities. ${ }^{33}$

30. Giuriato, Mikrographien (above, n. 21), pp. 223-268.

31. GS (above, n. 18), vol. 6, p. 804.

32. Giuriato, Mikrographien (above, n. 21), pp. 226-228.

33. GS (above, n. 18), vol. 6, p. 488: "Erinnerungen, selbst wenn sie ins Breite gehen, stellen nicht immer eine Autobiographie dar. Und dieses hier ist ganz gewiß keine. ... Denn die Autobiographie hat es mit der Zeit, dem Ablauf und mit dem zu tun, was den stetigen Fluß des Lebens ausmacht. Hier aber ist von einem Raum, von Augenblicken und vom Unstetigen die Rede" (Memories, even when they proliferate, do not always represent an autobiography. And this here is most certainly not one. ... The autobiography is concerned with time, with process, and with what makes up the continuous flow of life. But here it is all about space, moments, and the discontinuous). 
The point of Benjamin's recherche, the search for his own childhood, resides in how this search corresponded with that of the lost beginning of a text.

What has all this got to do with paper? For one thing, it must be said that his so-called diagram was written on a particular materialvery thin parchment paper, which is naturally no coincidence. Between 1928 and 1933 Benjamin had received from his friend Alfred Cohen various small parchment notebooks, about which, in a letter, he writes the following:

Since I know that you're to get another parchment notebook I've become more industrious and write away in this one this way and that. Indeed-to dwell on this for a moment; I mean that large notebook in the supple parchment cover that you gave me for a present in Mannheim. Using it like I have has also given me an embarrassing partiality for this very thin, transparent, and yet excellent paper that I can't find anywhere here. ${ }^{34}$

The transparency of this paper had obviously fascinated Benjamin. What he appreciated about it was that his own handwriting produced its mirror image on the reverse side of the page. Passages from other letters reveal that these parchment notebooks were Benjamin's favorite. Benjamin also used it for writing his first childhood memories under the title Berliner Chronik, from which I have already quoted the passage on his initial sketch of life (fig. 4).

A close look at this parchment notebook reveals how the ink presses through the extremely thin pages, which are almost entirely written solely on one side, to such an extent that mirror images of Benjamin's writing are indeed discernible. This would not be worth mentioning, however, if it were not for the fact that Benjamin's childhood memories themselves reveal a particular interest in the reversal generated by mirror images. On the page is a passage that tells of the "labyrinth of memory" and the art of "straying" - that is, straying through the labyrinth of a large city - which needs to be understood as an allegory of his own memory: "Not to find one's way in a city may well be uninteresting and banal. It requires ignorance-nothing more. But to lose oneself in a city-as one loses oneself in a forestthis calls for quite a different schooling. ... Paris taught me this art of straying; it fulfilled a dream that had shown its first traces in the labyrinths of the blotting pages of my school exercise books. ${ }^{\prime 35}$

34. GB (above, n. 18), vol. 3, p. 446 (letter from the end of February 1929).

35. GS (above, n. 18), vol. 6, p. 469: "Sich in einer Stadt nicht zurechtzufinden-das mag uninteressant und banal sein. Unkenntnis braucht es dazu-sonst nichts. In einer Stadt sich aber zu verirren-wie man in einem Wald sich verirrt-das bedarf schon 


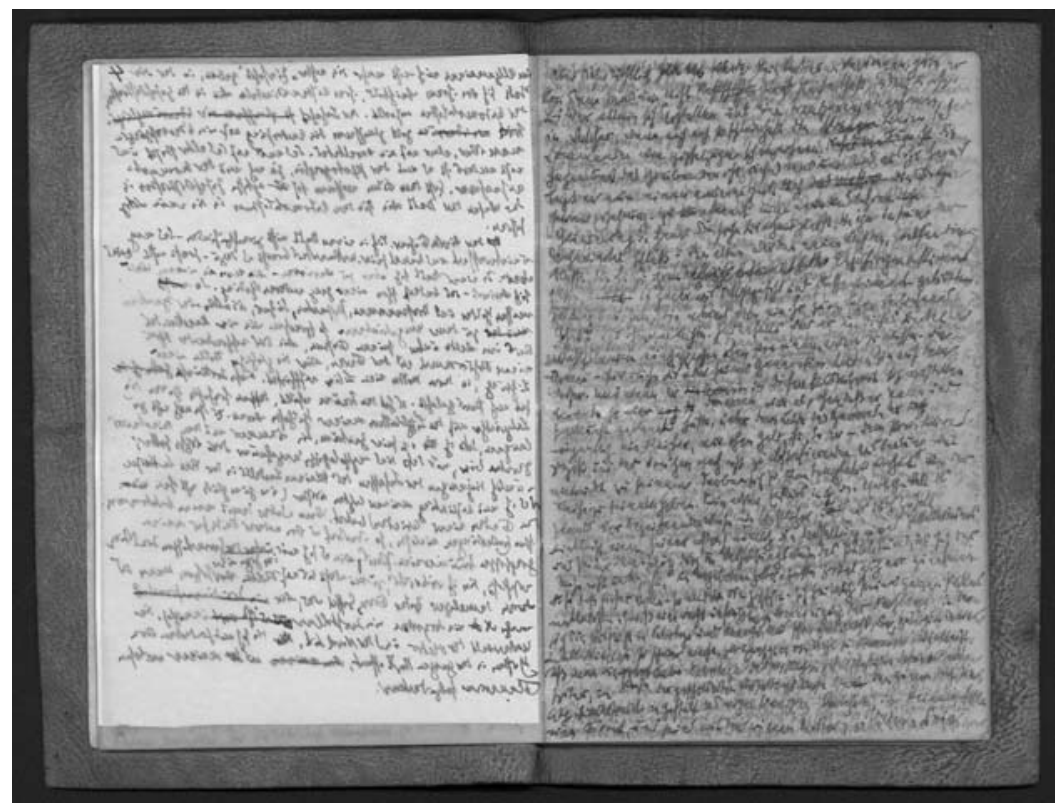

Figure 4. Walter Benjamin, Berliner Chronik (1932). (Source: Walter Benjamin Archiv, Berlin.)

The image of the labyrinth, inherent to remembering the abovementioned diagram (the graphical scheme), returns here. At the same time, we can read from where the labyrinth stems-namely, the blotting paper that had drawn the child into reverie.

What is a sheet of blotting paper? Blotting paper is a strange object that recurs as a motif in Benjamin's oeuvre in various contexts. It plunges under nibs, inkwells, and notebooks and resurfaces in passing and unobtrusively; it is an object with qualities that are more receptive than productive. By drying what is written with ink, blotting paper absorbs a remainder of what is written and preserves these traces in mirror-writing. Through this mirror-image absorption, the written is blotted, reproduced, and doubled. Here, a poetological reflection is discernible for Benjamin's childhood memories, which takes into consideration two separate though nonetheless inverted, corresponding writings in the act of blotting and absorbing: on the one side, a writing whose ink is fixed with the blotting

einer ganz anderen Schulung. . . . Diese Irrkünste hat mich Paris gelehrt; es hat den Traum erfüllt, dessen früheste Spuren die Labyrinthe auf den Löschblättern meiner Schulhefte waren." 
paper, and on the other, a labyrinthine writing that arises from the absorbed surplus ink of the first writing. The labyrinthine writing on the blotting paper is secondary and yet it is the focus of Benjamin's attention, for it is the second writing alone that can serve as teacher of the art of straying.

Given that this poetological privileging of the mirror-writing demonstrates a peculiar correspondence with Benjamin's writing practice and his handling of the parchment paper, the question arises as to what role the blotting paper, which is white, plays? As Benjamin's poetics of recycling knew nothing of white sheets, one could conclude that the blotting paper forms the negative equivalent of the blank page. As a figuration of the beginning, the blotting paper, in Benjamin's narrative, directs attention to the secondary residue of this beginning. By soaking up the primary writing while simultaneously reproducing it, the blotting paper detaches itself from the original in order to say something else, something its own.

As far as the blankness of the blotting paper is concerned, its advantage resides in how one does not have to, or indeed cannot, write on it directly; instead, it is distinguished by its receptive qualities and is written on via the detour of a first writing, as if of its own accord. In other words, this is the negative productivity of blotting paper. From this, one can finally conclude that Benjamin, in the form of blotting paper, considered white paper not only as secondary in production, but also in terms of destruction. It not only absorbs writing, but, at least in what the ambiguity of the name indicates, it also "blots out" - a logic inherent to the material, as Benjamin elsewhere emphasized: "If the blotting paper had its way, nothing that stands written would remain left over." ${ }^{\prime 36}$ In a certain sense, then, a sheet would not be blank at the very beginning, but actually at the end of this process, when everything on the page is blotted out, extinguished-a shiny white page.

\section{Conclusion}

Like other Modernist writers, Walter Benjamin shows a conscious sensitivity for the material particularities and dynamics inherent in his writing implements, both on the levels of reflecting on the media, as well as the specific uses of these media. Particular materials like parchment and blotting papers are important here, for they act as a type of reversible production: they demonstrate what one could call Benjamin's "aesthetics of negative production" - a poetics that

36. Ibid., vol. 5, pt. 1, p. 588: "Ginge es aber nach dem Löschblatt, so würde nichts, was geschrieben steht, übrig bleiben." 
not only conceptually, but also practically, proceeds on the basis of something already written.

For a comprehensive poetics of paper, the writing implement has to be considered in at least two respects: first, the concrete use of the instrument reminds us that paper is a material product with a history; and second, the subsequent metaphorical or poetological reflection has to question the extent to which the writing implement has been in-formed by this history in each specific case. The implement character of the paper is to be viewed, then, within the framework of a proper aesthetic of materials and considered in terms of what is being produced.

\section{Acknowledgment}

This essay was translated by Paul Bowman. 